\title{
PENGETAHUAN ORANG TUA TENTANG PERTUMBUHAN GIGI ANAK
}

\author{
Jumriani ${ }^{1}$, Sunomo Hadi ${ }^{2}$ \\ ${ }^{1}$ Poltekkes Kemenkes Makassar, ${ }^{2}$ Poltekkes Kemenkes Surabaya
}

\begin{abstract}
ABSTRAK
Pengetahuan sangat penting dalam mendasari terbentuknya sikap dan perilaku yang mendukung atau tidak mendukung kesehatan khususnya kesehatan gigi dan mulut. Terutama dalam hal ini Pengetahuan orang tua sangat penting dalam proses pertumbuhan dan perkembangan gigi anak nya. Pertumbuhan gigi sulung yang sangat berguna sebagai panduan pertumbuhan gigi tetap terutama pada masa usia sekolah dasar sebab pada masa-masa ini pergantian akan pertumbuhan gigi anak. Jenis penelitian ini adalah deskriptif yaitu penelitian yang dilakukan untuk mendapatkan gambaran pengetahuan orang tua tentang pertumbuhan gigi anak (studi pada pasien anak yang berkunjung di klinik gigi Amanah Makassar dengan sampel sebanyak 35 orang). Hasil penelitian menunjukkan bahwa pengetahuan orang tua kurang dalam hal periode pertumbuhan gigi dan persistensi. Kesimpulan dalam penlitian ini adalah pengetahuan orang tua tentang pertumbuhan gigi anak, yang meliputi periode pertumbuhan gigi dan persistensi di Klinik Gigi Amanah Makassar, termasuk dalam kategori kurang.
\end{abstract}

Kata kunci : gigi, orang tua, pengetahuan, pertumbuhan

\section{PENDAHULUAN}

Kesehatan gigi dan mulut merupakan bagian dari kesehatan tubuh yang tidak dapat dipisahkan satu dengan yang lainnya sebab kesehatan gigi dan mulut akan memperngaruhi kesehatan tubuh lainnya. Masalah tingginya angka penyakit gigi dan mulut saat ini salah satunya sangat dipengaruhi oleh faktor perilaku masyarakat.

Faktor dari perilaku masyarakat salah satunya dipengaruhi oleh rendahnya pengetahuan mengenai kesehatan khususnya kesehatan gigi dan mulut, Pengetahuan sangat erat kaitannya dengan sikap seseorang mengenai penyakit dan upaya pencegahannya.

Pengetahuan sangat penting dalam mendasari terbentuknya sikap dan perilaku yang mendukung atau tidak mendukung kesehatan khususnya kesehatan gigi dan mulut. Terutama dalam hal ini pengetahuan orang tua sangat penting dalam proses pertumbuhan dan perkembangan gigi anak nya. Pertumbuhan gigi sulung yang sangat berguna sebagai panduan pertumbuhan gigi tetap terutama pada masa usia sekolah dasar sebab pada masa-masa ini pergantian akan pertumbuhan gigi anak. Sehingga peran orang tua sangat diharapkan (Budiharto, 2009).

Perilaku orang tua terhadap kesehatan gigi dan mulut anak akan menentukan status kesehatan gigi anak kelak. Mulai tumbuhnya gigi yang merupakan proses penting dari pertumbuhan anak. Anak usia sekolah dasar merupakan suatu masa peralihan saat tanggalnya gigi susu dan saat tumbuhnya gigi tetap atau masa-masa periode gigi campuran. Usia ini merupakan usia yang dianggap rawan terhadap penyakit gigi dan mulut. Masalah yang sering terjadi pada gigi anak usia sekolah selain masalah karies yaitu persistensi gigi atau gigi berjejal (Fenanlampir, 2014).

Berdasarkan hasil riset kesehatan dasar nasionaal ( riskesda), tahun 2013, menyebutkan bahwa prevalensi nasional masalah kesehatan gigi dan mulut adalah 25,9 \% dengan proporsi kelompok umur 10-14 tahun sebanyak 25,2 \% dan kelompok umur 15-24 tahun sebanyak 24,3\%, sebuah penelitian dijawa timur, melaporkan bahwa sekitar 20,85\%. Anak-anak mengalami persistensi gigi sulung dimandibular sebanyak $66,23 \%$ dengan prevalensi tertinggi pada incisivus lateral. Dikota padang, angka kejadian gangguan perkembangan erupsi gigi dan persistensi mencapai 8.494 orang 
dengan angka tertinggi pada wilayah kerja puskesmas andalas sebanyak 1.020 orang.

Sehubungan dengan tingginya angka masalah kesehatan gigi khususnya yang berhubungan dengan perkembangan erupsi gigi dan persistensi maka menjaga kesehatan gigi dan mulut pada anak-anak merupakan hal yang sangat penting untuk diperhatikan oleh tenaga kesehatan maupun orang tua yang merupakan paling dekat dengan anak. Terutama pada masa sekolah merupakan masa dimulainya pergantian gigi, dari gigi sulung menjadi gigi permanen dan Gigi sulung sangat penting diperhatikan karena untuk menjaga lengkung gigi. (Maulani, 2005).

Gigi yang tumbuh pertama kali dilengkung rahang adalah gigi sulung. Gigi sulung manfaatnya untuk mempertahankan ruang untuk memberi tempat pada gigi permanen yang nantinya akan tumbuh. Gigi sulung juga memiliki fungsi yang hampir sama dengan gigi permanen, yaitu untuk mengunyah dan menghaluskan makanan. Gigi sulung juga membantu anak dalam berbicara, gigi yang lengkap dapat membuat ucapan lebih jelas (Hanna Y, 2018).

Kebanyakan orang tua mengabaikan pertumbuhan gigi anak sehingga menyebabkan gigi permanen yang akan tumbuh sebagai pengganti gigi susu tumbuh tidak beraturan. Pertumbuhan gigi yang kurang mendapat perhatian dari orang tua, maka tidak menutup kemungkinan pertumbuhan gigi anak akan tidak sempurna dikarenakan gigi akan tumbuh tidak pada tempatnya atau biasa disebut persistensi yaitu gigi akan tumbuh berjejal dan tidak rata, apabila gigi tumbuh berjejal dan berdesakan maka akan menyebabkan gigi sulit dibersihkan dan akan mudah terserang penyakit gigi berlubang (Karies). Selain itu gigi yang tumbuh tidak rata atau berjejal akan mempengaruhi psikis anak setelah anak tumbuh dewasa, anak akan merasa malu, minder dan rendah diri (Maulani, 2005)

Pengetahuan orang tua dapat dijadikan dasar untuk terbentuknya perilaku yang mendukung atau tidak mendukung kesehatan gigi dan mulut anak. Orang tua dengan pengetahuan yang kurang mengenai kesehatan gigi dan mulut merupakan faktor perilaku yang tidak mendukung kesehatan gigi dan mulut anak

Hasil survei awal dklinik amanah, cukup banyak kasus pencabutan gigi sulung dengan kasus persistensi gigi. Biasanya persistensi gigi pada anak-anak ini kurang mendapatkan perhatian dari orang tua, dikarenakan kurangnya pengetahuan orang tua terhadap waktu pergantian gigi akibatnya persistensi gigi masih sering ditemukan pada anak usia sekolah dasar. Oleh karena itu penulis tertarik untuk mengetahui Gambaran Pengetahuan Orang tua Tentang Pertumbuhan Gigi Anak (Studi Pada Pasien Anak Yang Berkunjung Di klinik gigi amanah).

Berdasarkan latar belakang tersebut diatas, maka penulis dapat merumuskan masalah dalam penelitian ini yaitu : "Bagaimana Gambaran Pengetahuan Orang Tua Tentang Pertumbuhan Gigi Anak Di Klinik gigi amanah Kota makassar ?" Tujuan Penelitian ini adalah untuk mengetahui gambaran pengetahuan orang tua tentang pertumbuhan gigi anak di Klinik Gigi Amanah Kota Makassar

\section{METODE PENELITIAN}

Jenis penelitian yang digunakan adalah deskriptif yaitu penelitian yang dilakukan untuk mendapatkan Gambaran Pengetahuan Orang Tua Tentang Pertumbuhan Gigi Anak (Studi Pada Pasien Anak Yang Berkunjung di Klinik gigi amanah makassar. Populasi dalam penelitian ini adalah seluruh orang tua pasien anak yang berkunjung ke Klinik Gigi Amanah Makassar. Sampel dalam penelitian ini adalah orang tua pasien anak yang berkunjung di klinik gigi amanah makassar. Pengambilan sampel dengan teknik accidental sampling, dan dilakukan dari bulan Januari sampai Februari 2020

Metode pengumpulan data penelitian ini diperoleh langsung dari pengisian kuisioner 
kepada orang tua anak di Ruang Klinik Gigi Amanah Makassar dengan kasus persistensi pada anaknya. Orang tua dan anak dipanggil secara urut satu persatu sesuai nomor urut pendaftaran pasien untuk dilakukan pemeriksaan. Pemerikasaan gigi pada pasien anak, untuk pasien dengan diagnosa persistensi maka akan diberikan lembar kuisioner kepada orang tua anak tentang pertumbuhan gigi untuk mengetahui pengetahuan orang tua tentang pertumbuhan gigi anak, selanjutnya oang tua meakukan Pengisian kuisioner dan Hasil kuisioner ditulis dan dimasukkan data.

Tingkat pengetahuan orang tua tentang pertumbuhan gigi dengan instrumen kuesioner dinilai dengan cara Setiap jawaban benar diberikan nilai 1 dan setiap jawaban salah diberikan nilai 0 , selanjutnya dimasukkan dalam kriteria Baik : 76\%100\%, Cukup : 56\%-76\% dan Kurang : $<55 \%$ (Nursalam, 2013)

Pengolahan data secara manual, Hasil kuisioner yang telah isi oleh responden, selanjutnya diolah, dijumlah dan di rata-ratakan kemudian di Persentase dan di laporkan dalam bentuk tabel distribusi

\section{HASIL DAN PEMBAHASAN}

Hasil

Hasil penelitian mengenai pengetahuan orang tua tentang pertumbuhan gigi di Klinik Gigi Amanah Makassar, yang telah dilaksanakan dengan jumlah sampel 35 orang tua anak yang umurnya antara 30- 42 tahun maka didapatkan hasil dan disitribusikan dalam bentuk tabel yang dibagi menjadi 2 tabel, yaitu tabel pengetahuan orang tua pasien anak tentang pertumbuhan gigi (tabel 1), tabel pengetahuan orang tua pasien anak tentang persistensi (tabel 2).

Tabel 1 menunjukkan bahwa terdapat $35,99 \%$ responden menjawab benar dan terdapat $63,99 \%$ menjawab salah, sehingga masuk dalam kategori kurang. Tabel .2 menunjukkan bahwa terdapat $41,42 \%$ responden menjawab benar dan terdapat 58,56 \% menjawab salah, sehingga masuk dalam kategori kurang.

\section{Pembahasan}

Berdasarkan hasil penelitian mengenai Gambaran Pengetahuan Orang Tua Tentang Pertumbuhan Gigi Anak di klinik gigi amanah makassar, menunjukkan bahwa Pada tabel pengetahuan Orang Tua Tentang periode Pertumbuhan Gigi didapatkan dari responden bahwa pengetahuan orang tua masuk dalam kategori kurang hal ini menunjukkan bahwa tingkat pengetahuan orang tua mengenai kesehatan gigi khususnya tentang masa pertumbuhan gigi anak, masih belum baik hal ini dapat disebabkan kurangnya informasi orang tua mengenai pentingnya periode pergantian gigi anak, padahal pengetahuan orang tua tentang kesehatan gigi merupakan faktor penting dalam upaya pemeliharaaan dan pencegahan terhadap penyakit gigi pada anak.

Selain itu hasil penelitian juga menunjukkan kepedulian orang tua terhadap usia tumbuh gigi pertama anak dan juga usia tanggal sangat kurang , padahal orang tua dan anak merupakan satu kesatuan ikatan dimana terutama ibu merupakan anggota tim kesehatan yang baik untuk melakukan pengawasan kesehatan (Eddy, 2015)

Hal sejalan dengan penelitian yang dilakukan oleh Munifah ( 2017), bahwa pengetahuan orang tua dalam hal ini ibu mengenai kondisi gigi sulung masih belum baik dan kategori cukup dan kebanyakan ibu tidak mengetahui usia tumbuh dan tanggal gigi anaknya.

Demikian halnya penelitian yang dilakukan oleh Manohar (2017), yang mengatakan bahwa hampir semua orang tua tidak mengetahui dengan benar kapan gigi anak pertama kali erupsi. 
Tabel 1. Distribusi Frekuensi Jawaban Pengetahuan Orang Tua Tentang Periode Pertumbuhan Gigi di Klinik Gigi Amanah Kota Makassar

\begin{tabular}{|c|c|c|c|c|c|c|}
\hline \multirow{3}{*}{ No } & \multirow{3}{*}{ Pernyataan } & \multicolumn{4}{|c|}{ Jawaban } & \multirow{3}{*}{$\begin{array}{l}\text { Kriteria } \\
\text { Penilaian }\end{array}$} \\
\hline & & \multicolumn{2}{|c|}{ Benar } & \multicolumn{2}{|c|}{ Salah } & \\
\hline & & $\Sigma$ & $\%$ & $\Sigma$ & $\%$ & \\
\hline 1 & $\begin{array}{l}\text { Pengetahuan terbentuk } \\
\text { nya benih gigi dalam } \\
\text { kandungan }\end{array}$ & 8 & 22,85 & 27 & 77,14 & \multirow{5}{*}{$\begin{array}{l}\text { Baik : } \\
76 \%-100 \% \\
\text { Cukup : } \\
56 \%-75 \% \\
\text { Kurang : } \\
<55 \%\end{array}$} \\
\hline 2 & $\begin{array}{l}\text { Pengetahuan jumlah } \\
\text { gigi sulung pada anak }\end{array}$ & 10 & 28,57 & 25 & 71,42 & \\
\hline 3 & $\begin{array}{l}\text { Pengetahuan usia gigi } \\
\text { permanen mulai } \\
\text { erupsi/tumbuh }\end{array}$ & 15 & 42,85 & 20 & 57,14 & \\
\hline 4 & $\begin{array}{l}\text { Pengetahuan usia } \\
\text { percampuran gigi } \\
\text { sulung dan gigi } \\
\text { permanen }\end{array}$ & 3 & 37,14 & 22 & 62,85 & \\
\hline 5 & $\begin{array}{l}\text { Pengetahuan usia gigi } \\
\text { permanen atau gigi } \\
\text { dewasa sudah mulai } \\
\text { lengkap dan tumbuh } \\
\text { semua }\end{array}$ & 17 & 48,57 & 18 & 51,42 & \\
\hline & Jumlah & 63 & 179,98 & 112 & 319,97 & \multirow{2}{*}{$\begin{array}{l}\text { Kategori } \\
\text { kurang }\end{array}$} \\
\hline & Rata-rata & 12,6 & 35,99 & 22,4 & 63,99 & \\
\hline
\end{tabular}

Tabel 2. Distribusi Frekuensi Jawaban Pengetahuan Orang Tua Tentang Persistensi di Klinik Gigi Amanah Kota Makassar

\begin{tabular}{|c|c|c|c|c|c|c|}
\hline \multirow{3}{*}{ No } & \multirow{3}{*}{ Pernyataan } & \multicolumn{4}{|c|}{ Jawaban } & \multirow{3}{*}{$\begin{array}{l}\text { Kriteria } \\
\text { Penilaian }\end{array}$} \\
\hline & & \multicolumn{2}{|c|}{ Benar } & \multicolumn{2}{|c|}{ Salah } & \\
\hline & & $\Sigma$ & $\%$ & $\Sigma$ & $\%$ & \\
\hline 1 & $\begin{array}{l}\text { Pengetahuan faktor } \\
\text { penyebab terjadinya gigi } \\
\text { bisa tumbuh berlapis } \\
\text { atau berjejal atau } \\
\text { persistensi }\end{array}$ & 18 & 51,42 & 17 & 48,57 & $\begin{array}{l}\text { Baik : } \\
76 \%- \\
100 \% \\
\text { Cukup : }\end{array}$ \\
\hline 2 & $\begin{array}{l}\text { Pengetahuan } \\
\text { penyebab gigi } \\
\text { berjejal karena } \\
\text { lambatnya } \\
\text { perkembangan } \\
\text { rahang }\end{array}$ & 12 & 34,28 & 23 & 65,71 & $\begin{array}{l}56 \%-75 \% \\
\text { Kurang : } \\
<55 \%\end{array}$ \\
\hline
\end{tabular}




\begin{tabular}{|c|c|c|c|c|c|c|}
\hline \multirow{3}{*}{ No } & \multirow{3}{*}{ Pernyataan } & \multicolumn{4}{|c|}{ Jawaban } & \multirow{4}{*}{$\begin{array}{l}\text { Kriteria } \\
\text { Penilaian }\end{array}$} \\
\hline & & \multicolumn{2}{|c|}{ Benar } & \multicolumn{2}{|c|}{ Salah } & \\
\hline & & $\Sigma$ & $\%$ & $\Sigma$ & $\%$ & \\
\hline 3 & $\begin{array}{l}\text { Pengetahuan yang } \\
\text { akan ditimbulkan } \\
\text { kalau gigi berlapis } \\
\text { dan berjejal atau } \\
\text { persistensi tidak } \\
\text { dicabut }\end{array}$ & 15 & 42,85 & 20 & 57,14 & \\
\hline 4 & $\begin{array}{l}\text { Pengetahuan waktu yang } \\
\text { tepat gigi goyang harus } \\
\text { di cabut }\end{array}$ & 13 & 37,14 & 22 & 62,85 & \\
\hline & Jumlah & 58 & 165,69 & 82 & 234,27 & \multirow{2}{*}{$\begin{array}{l}\text { Kategori } \\
\text { kurang }\end{array}$} \\
\hline & Rata-rata & 14,5 & 41,42 & 20,5 & 58,56 & \\
\hline
\end{tabular}

Gigi sulung merupakan gigi yang tumbuh pada masa kanak-kanak, keberadaan gigi sulung dalam rongga mulut merupakan faktor penting dalam menjaga integritas lengkung rahang selama perkembangan benih gigi tetap. Adapun fungsi gigi sulung dalam rongga mulut antara lain sebagai organ pengunyahan yang berperan penting dalam sistem pencernaan untuk menunjang nutrisi terhadap tumbuh kembang anak, selain itu juga fungsi gigi sulung juga menjaga estetik,fungsi bicara, penyedia ruang untuk gigi permanen dan sebagai penuntun gigi permanen yang akan erupsi. Dan juga berperan merangsang pertumbuhan dan perkembangan rahang (Suratri Mal ,2016)

Gigi tetap yang pertama muncul dalam rongga mulut / erupsi adalah gigi molar pertama, yang letaknya distak dari gigi molar ke dua. Gigi molar pertama sering dianggap oleh orang tua bisa mengalami pergantian sehingga mereka tidak begitu memperhatikannya, baru jika gigi terkena karies dan di bawa ke dokter gigi serta mendapatkan penjelasan, baru disadari bahwa gigi tersebut tidak dapat diganti lagi (Itjiningsih, 2015).

Dari hasil penelitian pada tabel 2, hasil kuesioner Tentang pengetahuan orang tua tentang persistensi didapatkan hasil juga pada kategori kurang. Hal ini disebabkan juga karena faktor
Pengetahuan yang sangat rendah tentang kesehatan gigi dan mulut, khususnya tentang Persistensi. Pengetahuan orang tua sangat penting dalam mendasari terbentuknya sikap dan perilaku. Menjaga kesehatan gigi dan mulut pada anak-anak merupakan hal perlu diperhatikan oleh orang tua terutama pada masa dimulai pergantian gigi dari gigi sulung ke gigi tetap (Worang, 2014). Kebanyakan orang tua ke dokter gigi menunggu gigi anaknya goyang dulu, padahal gigi permanen penggantinya tidak meresorbsi gigi sulung yang akan di gantikan sehingga terjadilah kasus persistensi atau gigi berjejal,

Hasil penelitian ini juga sejalan dengan peneltian yang dilakukan oleh Azifah (2010), menyatakan bahwa penyebab persistensi gigi yaitu kurangnya perhatian, pengetahuan, kesadaran orang tua beserta anak terhadap waktu pergantian gigi.

Rendahnya nilai pengetahuan orang tua mengenai persistensi menjadi salah satu penunjang tingginya angka pencabutan gigi karena persistensi, Orang tua cenderung kurang memperhatikan pertumbuhan gigi anaknya karena tidak mengetahui efek apa yang akan timbul akibat gigi berjejal. Gigi tetap yang akan tumbuh tanpa suatu petunjuk jalan yang betul mengakibatkan 
letak dari gigi tetap tersebut salah kedudukannya setelah erupsi.

Maka dari itu dalam proses pergantian gigi ini, sering kali gigi sulung atau susu tidak goyang, tetapi gigi tetap atau permanen sudah terlihat. Akibatnya jumlah gigi terlihat lebih banyak dan berjejal. Adapun Dampak negatif yang bisa ditimbulkan karena gigi berdesakan adalah estetika jelek rasa rendah diri dan percaya diri berkurang, penumpukan sisa makanan karena gigi sulit dibersihkan sehingga akan menimbulkan karies gigi. Fungsi pengunyahan juga dapat terganggu karena terjadi maloklusi karena gangguan pada gigi-gigi yang saling berhubungan. Fungsi bicara juga dapat terganggu karena, gigi sulung juga membantu anak dalam berbicara, gigi yang lengkap dapat membuat ucapan lebih jelas (Hanna Y,2018)

Kebanyakan Orang tua beranggapan bahwa gigi sulung merupakan gigi yang nantinya juga akan di gantikan oleh gigi permanen. Padahal gigi sulung berguna dan berpengaruh terhadap kesehatan individu, perkembangan rahang, erupsi gigi- geligi tetap, perkembangan fisik dan mental anak-anak karena dengan kehilangan dini gigi sulung, mengakibatkan perkembangan rahang yang normal tidak mungkin terjadi dan gigi molar pertama tidak dapat tumbuh pada posisi yang normal sebagai kunci dari oklusi (Itjiningsih, 2015).

Setiap orang tua bertanggung jawab dalam suatu keluarga atau tugas rumah tangga yang dalam kehidupan sehari-hari disebut sebagai bapak dan ibu. Seorang ahli dalam buku psikologi untuk keluarga, mengatakan bahwa orang tua merupakan individu yang berbeda dengan membawa pandangan, pendapat dan kebisaankebiasaan sehari-hari (Gunarsa, 2014). Hal lain kemungkinan karena kurangnya penyuluhan atau informasi. Menurut Prianggajati (2013), dengan banyaknya orang mendengarkan penyuluhan, maka pengetahuan seseorang akan bertambah dan dapat merubah perilaku.

Untuk meningkatkan derajat kesehatan gigi dan mulut tenaga kesehataan gigi perlu memberikan penyuluhan dan informasi secara intensif semakin baik dan semakin banyak informasi yang diterima maka semakin baik dan mudah seseorang mendapatkan pengetahuan.

\section{SIMPULAN DAN SARAN}

\section{Simpulan}

Berdasarkan hasil penelitian dan pembahasan tentang gambaran pengetahuan orang tua tentang pertumbuhan gigi anak, maka dapat disimpulkan bahwa : Pengetahuan orang tua tentang pertumbuhan gigi yang meliputi periode pertumbuhan gigi dan persistensi di Klinik gigi Amanah makassar, termasuk dalam kategori kurang.

\section{Saran}

Berdasarkan kesimpulan diatas maka disarankan bagi orang tua anak yang pengetahuannya kurang tentang kesehatan gigi khususnya tentang pertumbuhan gigi anak agar dapat meningkatkan pengetahuan dengan memperbanyak informasi dari berbagai sumber seperti televisi, buku, majalah, perbincangan social tentang kesehatan, mencari informasi melalui internet serta control kesehatan gigi anak ke pelayanan kesehatan gigi bukan hanya pada saat ada keluhan. Bagi tenaga kesehatan sebaiknya perlu mengadakan penyuluhan tentang pentingnya mengetahui pertumbuhan gigi kepada orang tua dan secara sederhana kepada anak, lalu mengadakan pemeriksaan kesehatan gigi dan mulut, guna melihat pertumbuhan gigi anak.

\section{DAFTAR PUSTAKA}

Azifah, 2010. "Gambaran Kasus Pencabutan Gigi Persistensi di Poliklinik Gigi Rumah Sakit Ibu dan Anak Pemerintah Aceh Tahun 2010". Jurnal. Banda Aceh: Universitas Syiah Kuala

Eddy E, Mutiara H,2010, Peranan ibu dalam pemeliharaan kesehatan gigi terhadap status karies gigi balita, Dentika dental journal.

Budiharto, 2009. Pengantar IImu Perilaku Kesehatan dan Pendidikan Kesehatan Gigi. Jakarta : EGC 
Gunarsa, 2003. Psikologi Untuk Keluarga . Jakarta : Gunung Mulia

Fenanlampir, 2014 "Gambaran Indikasi Pencabutan Gigi Dalam Periode Gigi Bercampur Pada Siswa SMP Negeri Langowan",Jurnal e-Gigi (eG,Vol 2, No 2.

Munifah Abdat, 2017, Pengetahuan sikap ibu mengenai gigi sulung anaknya serta kemauan melakukan perawatan, cakradonya.journal, vol 1

Maulani, 2005. "Kiat Merawat Gigi Anak Panduan Orang Tua Dalam Menjaga Kesehatan Gigi Bagi Anak-Anaknya". Jakarta : PT. Elex Media Komputindo.

Manohar J, Mani G, 2017, knowledge and attitude of parent regarding children's primary teeth and their willingness for treatment. Jounal of pharmaceutical science and research. 9 no 2.

Hanna, Y, 2018. "Apa Fungsi Gigi Susu" 14 Januari 2018 Home/iptek https://www.google.com

Itjingningsih, 2015. Anatomi Gigi Edisi 2. Jakarta: EGC "Hubungan Tingkat Pengetahuan Orang
Tua Dengan Kebersihan Gigi dan Mulut Anak di TK Tunas Bhakti Manado", jurnal e-Gigi. Vol 2 No 2.

Indriyanti R, 2006 "Pola Erupsi Gigi Permanen Ditinjau Dari Usia Kronologis Pada Anak Usia 6 Sampai 12 Tahun". Laporan Penelitian. Bandung : FKG UNPAD

Prianggajati, 2013. Jurnal EduHealth. Diterbitkan oleh Fakultas IImu Kesehatan Universitas Pesantren Tinggi Darul Ulum Jombang Volume 3 nomor 2, September 2013

Suratri Mal, Sintawati, andayasari, 2016, pengetahuan, sikap dan perilaku orang tua tentang kesehatan ggi dan mulut pada anak usia taman kanak-kanak di provinsi banten . Jakarta. Media litbangkes.

Worang, 2014 "Dukungan sosial keluarga dan perilaku anak dengan karies gigi dalammelakukan perawatan gigi dan mulut' https://scholar.google.co.id/scholar?hl=en\&as $\mathrm{sdt}=0 \% 2 \mathrm{C} 5 \& \mathrm{q}=+$ pergantin+gigi worang+2014\&btnG $=$ 